Pediat. Res. 6: 584-592 (1972)

Acidosis

carbon dioxide

fetus hydrogen ion

lactate

newborn

\title{
Elimination of Hydrogen Ion by the Lamb Fetus and Newborn
}

\author{
S. S. Daniel, R. A. Baratz, E. T. Bowe, A. I. Hyman, H. O. Morishima, \\ S. R. SARcia, and L. S. James ${ }^{[44]}$ \\ Division of Perinatal Medicine of the Departments of Anesthesiology, Obstetrics and Gynecology, and Pediatrics, \\ College of Physicians and Surgeons, Columbia University and Babies Hospital, New York, New York, USA
}

\section{Extract}

Response of the fetal lamb to metabolic acidosis in the absence of hypoxia or maternal acidosis was studied and compared with that of the newborn lamb. Experiments were conducted on nonanesthetized fetuses intact in utero, catheters having been implanted previously at hysterotomy. Metabolic acidosis was produced by infusion of $28 \mathrm{mmoles}$ of lactic or hydrochloric acid $(0.25 \mathrm{~m})$ into the femoral vein of fetus or newborn.

Similar changes in acid-base state were produced with hydrochloric and lactic acids. In fetuses, $\mathrm{pH}$ fell $0.28 \mathrm{pH}$ units; this decrease was greater than that observed in newborns $(0.20 \mathrm{pH}$ units). Newborns hyperventilated during and following infusion, lowering $\mathrm{P}_{\mathrm{CO}_{2}}$ by an average of $8 \mathrm{~mm} \mathrm{Hg}$ and partially compensating for the metabolic acidosis. In fetuses, arterial $\mathrm{P}_{\mathrm{CO}_{2}}$ rose during infusion by an average of 6 $\mathrm{mm} \mathrm{Hg}$, but values for $\mathrm{P}_{\mathrm{CO}_{2}}$ in umbilical vein and maternal artery did not change. Thus fetal A-V difference for $\mathrm{P}_{\mathrm{CO}_{2}}$ across the placenta increased, whereas the $\mathrm{P}_{\mathrm{CO}_{2}}$ gradient between fetus and mother remained constant. These observations suggest that fetal ability to compensate for metabolic acidosis is limited by the maternal $\mathrm{Pa}_{\mathrm{CO}_{2}}$.

Upon completion of the acid infusion, $\mathrm{pH}$ rose and base deficit fell at approximately the same rate in both fetus and newborn, but the rate of recovery was slow. After $1 \mathrm{hr}, \mathrm{pH}$ was still significantly lower than the control value (by $0.1 \mathrm{pH}$ unit) and base deficit was lower by $9 \mathrm{mEq} /$ liter. By $12 \mathrm{hr}$, all acid-base values had returned to normal.

\section{Speculation}

These experiments indicate that the transfer of hydrogen ion across the placenta is relatively slow, even when the circulatory status of both mother and fetus is normal, and there is no fetal hypoxia or uterine contraction. In this respect the placental membrane has properties similar to the blood brain "barrier." With strong uterine contractions, maternal perfusion of the intervillous space is reduced or ceases, which leads to successive episodes of fetal hypoxia and acidosis. Slow placental transfer of hydrogen ion may explain the development of metabolic acidosis in the fetus during the course of labor. 


\section{Introduction}

During labor and delivery, metabolic acidosis develops in the fetus. It seems to be due primarily to episodes of hypoxia suffered by the fetus during uterine contractions [24, 30]. If the mother also becomes acidotic as a result of dehydration and excessive muscular activity, this will aggravate the fetal acidosis $[3,7]$.

From comparative studies of maternal and fetal blood during normal labor or at delivery, it has been inferred that fixed acids are transferred across the placenta in both directions $[3,11,14,18,26,31,36]$. Some investigators have concluded that movement of specific anions, such as bicarbonate and lactate, across the placenta is passive [16], whereas others believe that the placenta is impermeable to them [5, 6, 9, 21, 22]. Most of these data were obtained during labor, delivery, or surgical procedures; under such conditions there is likely to be variable interference with uterine and placental circulations and hence with maternal-fetal exchange.

The present experiments were undertaken in fetal lambs to determine the rate of clearance of an acid load by the feto-placental unit. Hydrochloric or lactic acid was infused into the unanesthetized fetus, in which catheters had been previously implanted, and under conditions in which there was neither fetal hypoxia nor maternal acidosis and in which the maternofetal relation had stabilized. Responses of the fetoplacental unit and of the newborn lamb to a similar acid load were compared [12]. Both hydrochloric and lactic acids were studied in order to determine whether metabolism of lactate by the fetus or feto-placental unit made a significant contribution to the rate at which the fetus recovered from severe metabolic acidosis.

\section{Materials and Methods}

\section{Fetal Experiments}

Nine pregnant Dorset sheep of known gestational age ranging from 103 to 132 days were used (term is 147-150 days). Experiments were carried out after a 24-hr period of starvation. Anesthesia was induced with sodium thiopental, $5-7 \mathrm{mg} / \mathrm{kg}$, administered intravenously. This was followed by succinylcholine hydrochloride, $2 \mathrm{mg} / \mathrm{kg}$, and endotracheal intubation. Anesthesia was maintained with a mixture of $1 \%$ halothane, oxygen, and nitrous oxide. Respiration was con- trolled, with rate and volume adjusted to maintain a normal maternal arterial $\mathrm{pH}$ and $\mathrm{P}_{\mathrm{CO}_{2}}$ [25].

The abdomen was opened with a paramedian incision, the uterus was incised and a fetal hind limb was delivered, while excessive loss of amniotic fluid was avoided. The femoral artery and vein were cannulated with polyvinyl catheters, the tips of which were advanced to the abdominal aorta and inferior vena cava, respectively. After the femoral incision was closed, the fetal leg was replaced and the uterus was closed. In some instances another soft plastic catheter was inserted into one of the cotyledonary veins and advanced toward the fetus so that the tip was in a major umbilical vein. A catheter was also placed in the maternal abdominal aorta through a superficial branch of the femoral artery. All catheters were tunneled subcutaneously to the back of the ewe and were secured in a plastic cup sutured over the cutaneous stoma. The intravascular catheters were filled with aqueous heparin ( $1000 \mathrm{U} / \mathrm{ml}$ ) and refilled as long as the preparation was in use.

After the operation, the animal was allowed to recover for 4-24 hr. Blood gases and pH of both fetus and mother were in the normal range before acid was infused into the fetus. One fetus was studied twice on consecutive days after it was ascertained by the acidbase status that both mother and fetus had recovered from the previous study.

\section{Newborn Experiments}

Eight spontaneously delivered newborn lambs less than a week old ( $1-5$ days) were sedated with sodium secobarbital (15 mg/ $\mathrm{kg}$ ) administered intramuscularly. Polyvinyl catheters were placed in the femoral artery and vein. Animals breathed spontaneously throughout the experiments. Rectal temperature was maintained between $38-39^{\circ}$ by means of a heating lamp.

\section{Infusion of Acid}

Twenty-eight millimoles of either hydrochloric or lactic acid (112 $\mathrm{ml}$ of $0.25 \mathrm{~m}$ solutions) was infused at a constant rate by means of a pump [38] $1 \mathrm{hr}$ through the femoral vein catheter into the fetal or newborn lamb. Each acid was infused into 5 fetal and 4 newborn lambs. It was not possible to give an exactly similar acid load to fetus and newborn on a per kilogram basis for two reasons. Weight of the fetus was not known and the infusion solution was distributed throughout both fetus and placenta. After some preliminary experiments, it was found that 28 mmoles of 
Table I. Summary of experiments ${ }^{1}$

\begin{tabular}{|c|c|c|c|c|c|}
\hline Group & $\begin{array}{l}\text { No. of } \\
\text { animals }\end{array}$ & State & $\begin{array}{l}\text { Mean gestational or } \\
\text { postnatal age, days }\end{array}$ & Mean wt, kg & Acid infusion, mmoles $/ \mathrm{kg}$ \\
\hline$I$ & 5 & Fetal & $\begin{array}{c}115 \\
(103-128)\end{array}$ & $\begin{array}{c}3.07 \\
(2.50-3.65)\end{array}$ & $\mathrm{HCl}, 8.1^{2}$ \\
\hline$I I$ & 4 & Neonatal & $\begin{array}{l}4.5 \\
(1-5)\end{array}$ & $\begin{array}{c}4.23 \\
(3.35-5.15)\end{array}$ & $\mathrm{HCl}, 6.6$ \\
\hline$I I I$ & 5 & Fetal & $\begin{array}{c}128 \\
(121-132)\end{array}$ & $\begin{array}{c}2.90 \\
(1.90-3.90)\end{array}$ & Lactic acid, $8.4^{2}$ \\
\hline$I V$ & 4 & Neonatal & $\begin{array}{c}1.5 \\
(1-3)\end{array}$ & $\begin{array}{c}3.55 \\
(2.05-6.20)\end{array}$ & Lactic acid, 7.9 \\
\hline
\end{tabular}

1 Range appears in parentheses.

${ }^{2}$ This figure includes the total weight of the fetus and placenta.

$0.25 \mathrm{M}$ acid solutions gave a suitable change in $\mathrm{pH}$ in both the smaller fetus and the mature newborn lamb (Table I). Maternal, fetal, and newborn arterial blood pressures and heart rates were monitored with gauge transducers [39] on a multichannel polygraph. Blood was sampled intermittently from the umbilical vein and from fetal, maternal, and newborn arteries before, during, and after acid infusion.

In 5 experiments, fetal arterial blood was obtained 12-24 hr postinfusion. Samples were not obtained from the 4 other animals because of mechanical obstruction in the catheter (2), premature stillbirth (1), and fetal death from hemorrhage (1).

Blood $\mathrm{pH}, \mathrm{P}_{\mathrm{CO}_{2}}$, and $\mathrm{P}_{\mathrm{O}_{2}}$ were determined with a $\mathrm{pH}$ meter [40] and gas monitor, with micro glass electrode, Severinghaus type $\mathrm{P}_{\mathrm{CO}_{2}}$ electrode, and Clark type $\mathrm{P}_{\mathrm{O}_{2}}$ electrode, respectively; base deficit was calculated with the Siggaard-Andersen nomogram [33]. In studies with $\mathrm{HCl}$, serum chloride was determined with a chloridometer [41]. In lactic acid infusion experiments, lactate and pyruvate levels were determined by a micromodification of the methods of Barker and Summerson [2] and Friedemann and Haugen [15], respectively.

\section{Results}

Mean blood gas and acid-base data for fetal and newborn arterial blood before the infusion, at its completion, and $1 \mathrm{hr}$ later are presented in Table II. Serial changes during and following acid infusion are depicted in Figures 1 and 2.

\section{Changes in Acid-Base}

The fall in $\mathrm{pH}$ during infusion of both acids was greater in fetus than in newborn $(P<0.01)$ (Table II). However, after completion of the infusions, $\mathrm{pH}$ rose at almost the same rate in both fetus and newborn.
Changes in $\mathrm{pH}$ were similar after hydrochloric acid and lactic acid infusion (Figs. 1 and 2, Table II). Results were identical whether the means were computed from individual $\mathrm{pH}$ values or were first converted into hydrogen ion concentrations.

$\mathrm{P}_{\mathrm{CO}_{2}}$ of fetal arterial blood rose by a mean of 3.4 $\mathrm{mm} \mathrm{Hg}$ in the $\mathrm{HCl}$ group and by $8.7 \mathrm{~mm} \mathrm{Hg}$ in the lactic group at the end of acid infusion. One hour after completion of infusion, $\mathrm{P}_{\mathrm{CO}_{2}}$ had returned to control levels. By comparison, $\mathrm{P}_{\mathrm{CO}_{2}}$ in newborns fell during and following infusion, by $11 \mathrm{~mm} \mathrm{Hg}$ with $\mathrm{HCl}$, and by $7.5 \mathrm{~mm} \mathrm{Hg}$ with lactic acid. Except for the rise in fetal arterial $\mathrm{P}_{\mathrm{CO}_{2}}$ with $\mathrm{HCl}$ infusion, all these changes were significant at the $95 \%$ confidence limit.

Changes in base deficit in arterial blood were similar in fetuses and newborn lambs which received $\mathrm{HCl}$ (groups I and II), and in fetuses which received lactic acid (group III) (Table I). In group IV, newborn lambs which received lactic acid, the rise in base deficit was smaller, $11.2 \mathrm{mEq} /$ liter at the end of infusion, compared with values of $15.7,16.0$, and $17.7 \mathrm{mEq} /$ liter for groups $I, I I$, and $I I I$, respectively. One hour after the completion of acid infusion, mean base deficit was still 6-12 mEq/liter; these levels were significantly higher than control values in all groups $(P<0.01)$.

In the five animals in which a fetal arterial blood sample was obtainable 12-24 hr postinfusion, mean $\mathrm{pH}$ was 7.35 (range, 7.31-7.42); $\mathrm{P}_{\mathrm{CO}_{2}}, 47.8 \mathrm{~mm} \mathrm{Hg}$; base deficit, $1.5 \mathrm{mEq} /$ liter; and $\mathrm{P}_{\mathrm{O}_{2}}, 19 \mathrm{~mm} \mathrm{Hg}$. These values are not significantly different from those of controls.

\section{Changes in Anion}

Lactic acid infusion caused a rise in blood lactate concentrations in both fetus and newborn, the rise being somewhat smaller in the latter (Fig. 1, Table II). The values fell over the next hour but were still signif- 
Table II. Variables in arterial blood of fetal and newborn lambs at the completion of and $1 \mathrm{hr}$ after end of acid infusion ${ }^{1}$

\begin{tabular}{|c|c|c|c|c|}
\hline & \multicolumn{2}{|c|}{ Hydrochloric acid infusion } & \multicolumn{2}{|c|}{ Lactic acid infusion } \\
\hline & Group I (fetus) & Group II (newborn) & Group III (fetus) & Group IV (newborn) \\
\hline $\mathrm{pH}$ in control & $7.33 \pm 0.012$ & $7.36 \pm 0.014$ & $7.36 \pm 0.023$ & $7.40 \pm 0.009$ \\
\hline$\Delta \mathrm{pH}$ at end of infusion & $-0.27 \pm 0.018$ & $-0.22 \pm 0.015$ & $-0.29 \pm 0.043$ & $-0.17 \pm 0.019$ \\
\hline$\Delta \mathrm{pH}$ l hr later & $-0.13 \pm 0.025$ & $-0.13 \pm 0.018$ & $-0.09 \pm 0.025$ & $-0.07 \pm 0.024$ \\
\hline $\begin{array}{l}\text { Base deficit in control, } \\
\mathrm{mEq} / \text { liter }\end{array}$ & $1.3 \pm 0.50$ & $3.6 \pm 0.75$ & $0.0 \pm 1.78$ & $1.6 \pm 0.64$ \\
\hline $\begin{array}{l}\Delta \text { Base deficit at end of in- } \\
\text { fusion }\end{array}$ & $+15.7 \pm 1.63$ & $+16.0 \pm 0.94$ & $+17.7 \pm 1.38$ & $+11.2 \pm 0.82$ \\
\hline$\Delta$ Base deficit 1 hr later & $+9.1 \pm 1.70$ & $+12.1 \pm 0.75$ & $+9.0 \pm 1.28$ & $+6.1 \pm 0.73$ \\
\hline $\begin{array}{l}\text { [Anion] in control, } \\
\text { mmoles/liter }\end{array}$ & $105.6 \pm 1.80(\mathrm{Cl})^{2}$ & $112.3 \pm 1.37(\mathrm{Gl})$ & $3.4 \pm 0.43(\mathrm{Lac})^{3}$ & $1.9 \pm 0.25(\mathrm{Lac})$ \\
\hline $\begin{array}{l}\Delta[\text { Anion }] \text { at end of infu- } \\
\text { sion }\end{array}$ & $+7.2 \pm 2.25$ & $+14.0 \pm 3.20$ & $+12.9 \pm 0.95$ & $+10.8 \pm 0.63$ \\
\hline$\Delta[$ Anion $] 1 \mathrm{hr}$ later & $+11.0 \pm 3.20$ & $+9.7 \pm 4.60$ & $+7.8 \pm 0.06$ & $+6.6 \pm 0.42$ \\
\hline $\mathrm{P}_{\mathrm{CO}_{2}}$ in control, $\mathrm{mm} \mathrm{Hg}$ & $51.6 \pm 2.24$ & $35.3 \pm 1.46$ & $42.8 \pm 1.09$ & $37.0 \pm 0.50$ \\
\hline$\Delta \mathrm{P}_{\mathrm{CO}_{2}}$ at end of infusion & $+3.4 \pm 2.55$ & $-11.0 \pm 3.30$ & $+8.7 \pm 2.44$ & $-6.0 \pm 1.60$ \\
\hline$\Delta \mathrm{P}_{\mathrm{CO}_{2}} 1 \mathrm{hr}$ later & $+5.6 \pm 2.00$ & $-5.3 \pm 2.70$ & $-0.2 \pm 0.66$ & $-2.7 \pm 0.23$ \\
\hline $\mathrm{P}_{\mathrm{O}_{2}}$ in control, $\mathrm{mm} \mathrm{Hg}$ & $20.5 \pm 0.66$ & $70.8 \pm 2.65$ & $19.0 \pm 1.89$ & $64.0 \pm 3.03$ \\
\hline$\Delta \mathrm{P}_{\mathrm{O}_{2}}$ at end of infusion & $+6.3 \pm 1.67$ & $+12.0 \pm 3.10$ & $+2.0 \pm 1.07$ & $+7.5 \pm 1.25$ \\
\hline$\Delta \mathrm{P}_{\mathrm{O}_{2}} 1 \mathrm{hr}$ later & $+2.5 \pm 1.04$ & $+12.2 \pm 4.77$ & $+0.0 \pm 0.80$ & $+5.0 \pm 2.40$ \\
\hline $\begin{array}{l}\text { [Pyruvate] in control, } \\
\text { mmoles/liter }\end{array}$ & & & $0.28 \pm 0.058$ & $0.22 \pm 0.025$ \\
\hline $\begin{array}{l}\Delta[\text { Pyruvate }] \text { at end of in- } \\
\text { fusion }\end{array}$ & & & $+0.09 \pm 0.026$ & $+0.15 \pm 0.027$ \\
\hline$\Delta[$ Pyruvate $]$ l hr later & & & $+0.01 \pm 0.038$ & $+0.02 \pm 0.030$ \\
\hline
\end{tabular}

Values are expressed as mean \pm standard error.

$\mathrm{Cl}$ : chloride.

Lac: lactate.

icantly higher $(P<0.01)$ than control levels at the end of this period. Similarly, infusion of $\mathrm{HCl}$ caused a rise in plasma chloride. The increase in plasma chloride was less in fetus than in newborn, and the level continued to rise in the hour following infusion (Fig. 2, Table II).

\section{Changes in $P_{O_{2}}$}

Acid infusion caused a rise in arterial blood $\mathrm{P}_{\mathrm{O}_{2}}$ both in fetus and newborn. Changes were greater in those which received $\mathrm{HCl}$, and greater in newborn than in fetus (Table II). $\mathrm{P}_{\mathrm{O}_{2}}$ remained elevated $1 \mathrm{hr}$ after completion of infusion. In fetuses which received lactic acid, the rise in $\mathrm{P}_{\mathrm{O}_{2}}$ was not significant $(P<$ $0.05)$.

\section{Fietal $A-V$ Difference across the Placenta}

Fetal A-V gradient across the placenta between umbilical artery and vein was similar with either acid. The $\mathrm{pH}$ difference increased slightly from 0.02 to 0.05 after acid infusion and remained constant throughout the infusion; it returned toward control values $1 \mathrm{hr}$ after completion of infusion. The difference for $\mathrm{P}_{\mathrm{CO}_{2}}$ increased during infusion from $7 \mathrm{~mm} \mathrm{Hg}$ and it reached a maximum of $17 \mathrm{~mm} \mathrm{Hg}$ at the end of infusion; $1 \mathrm{hr}$ later the difference was $3 \mathrm{~mm} \mathrm{Hg}$, which was not significantly different from control values. The difference for base deficit was $0.5 \mathrm{mEq} /$ liter prior to infusion and $0.8 \mathrm{mEq} /$ liter at the completion of and $1 \mathrm{hr}$ after infusion. There was no measurable difference in lactate concentration in umbilical vein and fetal femoral artery blood throughout the experiment (Fig. 3).

The difference in $\mathrm{P}_{\mathrm{O}_{2}}$ between umbilical vein and fetal artery blood fell from 16 to $10 \mathrm{~mm} \mathrm{Hg}$ following acid infusion; it returned to pre-infusion level $\mathrm{l} \mathrm{hr}$ later.

Acid-base values in the arterial blood of the unanesthetized mother before, during, and after acid infusion to the fetus were not significantly changed (Table III). Mean maternal arterial pressure prior to acid infusion was $75 \pm 4.2 \mathrm{~mm} \mathrm{Hg}$; it remained stable throughout the experiment. Although there was a tendency for the fetal heart rate to rise at the completion of infusion, from a mean of $194 \pm 14$ (SE) beats/ $\min$ to $208 \pm 16$, the increase was not significant. Mean blood pressure in the fetuses prior to infusion 


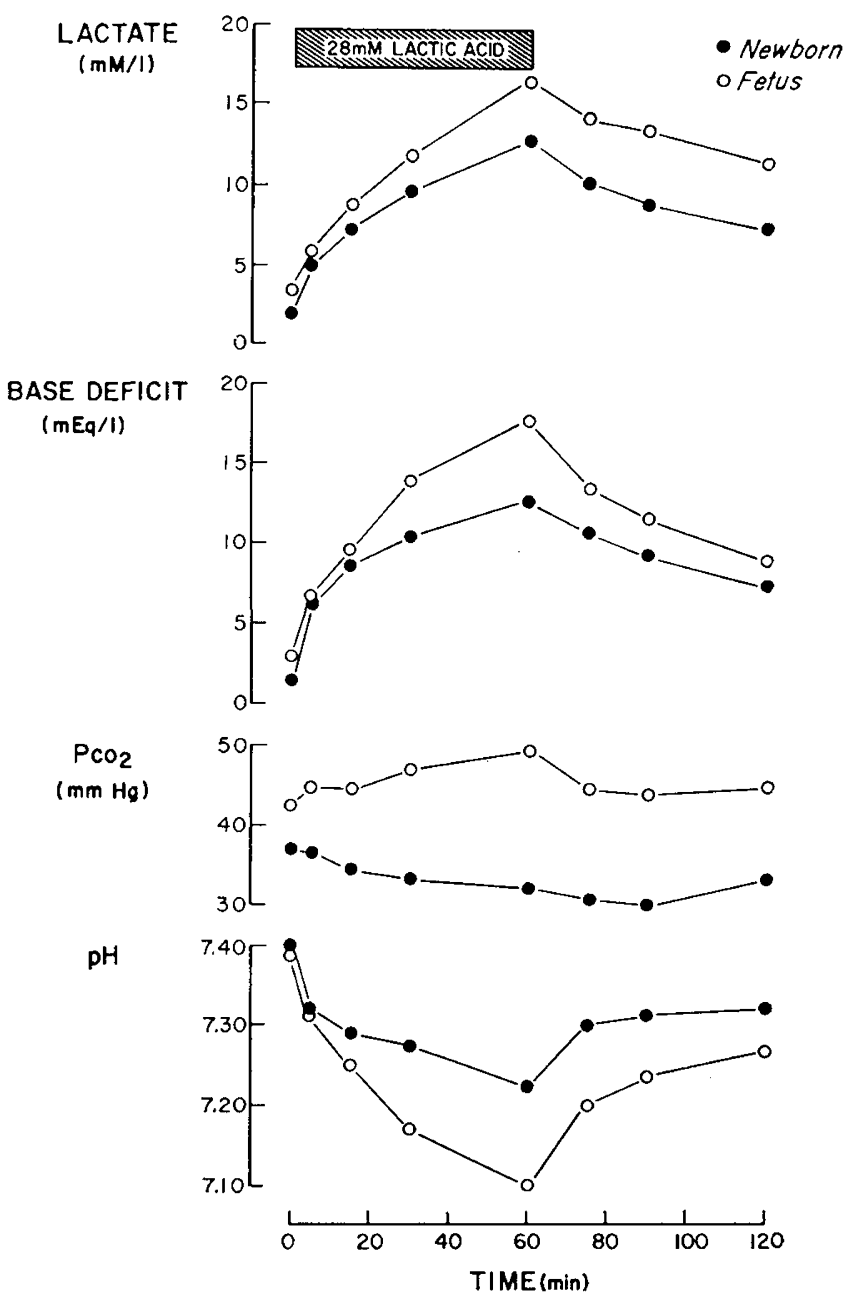

Fig. 1. Mean arterial $\mathrm{pH}, \mathrm{P}_{\mathrm{CO}_{2}}$, base deficit, and lactate during and after lactic acid infusion in fetal and newborn lambs. Each point represents four or five experiments.

was $46 \pm 4.0 \mathrm{~mm} \mathrm{Hg}$ and it did not change significantly. In the newborn lamb, mean blood pressure rose from $95 \pm 8.2 \mathrm{~mm} \mathrm{Hg}$ to $103 \pm 13.1$ and heart rate fell from $225 \pm 20$ beats $/ \mathrm{min}$ to $207 \pm 35$ during infusion, but these changes also were not significant.

In newborn lambs, respiratory rate increased significantly during acid infusion. Change was apparent within $5 \mathrm{~min}$ and, by the end of infusion, it had increased from a mean of $79 / \mathrm{min}$ to $116 / \mathrm{min}$. Tachypnea persisted for at least $45 \mathrm{~min}$ after completion of infusion.

\section{Discussion}

These experiments indicate that fetal recovery from metabolic acidosis produced by infusion of hydrochlo- ric or lactic acid is slow. The ability of the fetus to handle an acid load is not superior to that of the newborn lamb.

The initial fall in anion concentration in both fetus and newborn following completion of infusion is probably due to distribution. This has been inferred since the initial fall in plasma chloride after infusion of $\mathrm{NaCl}$ into children and experimental animals has been shown to be due to its distribution in the chloride

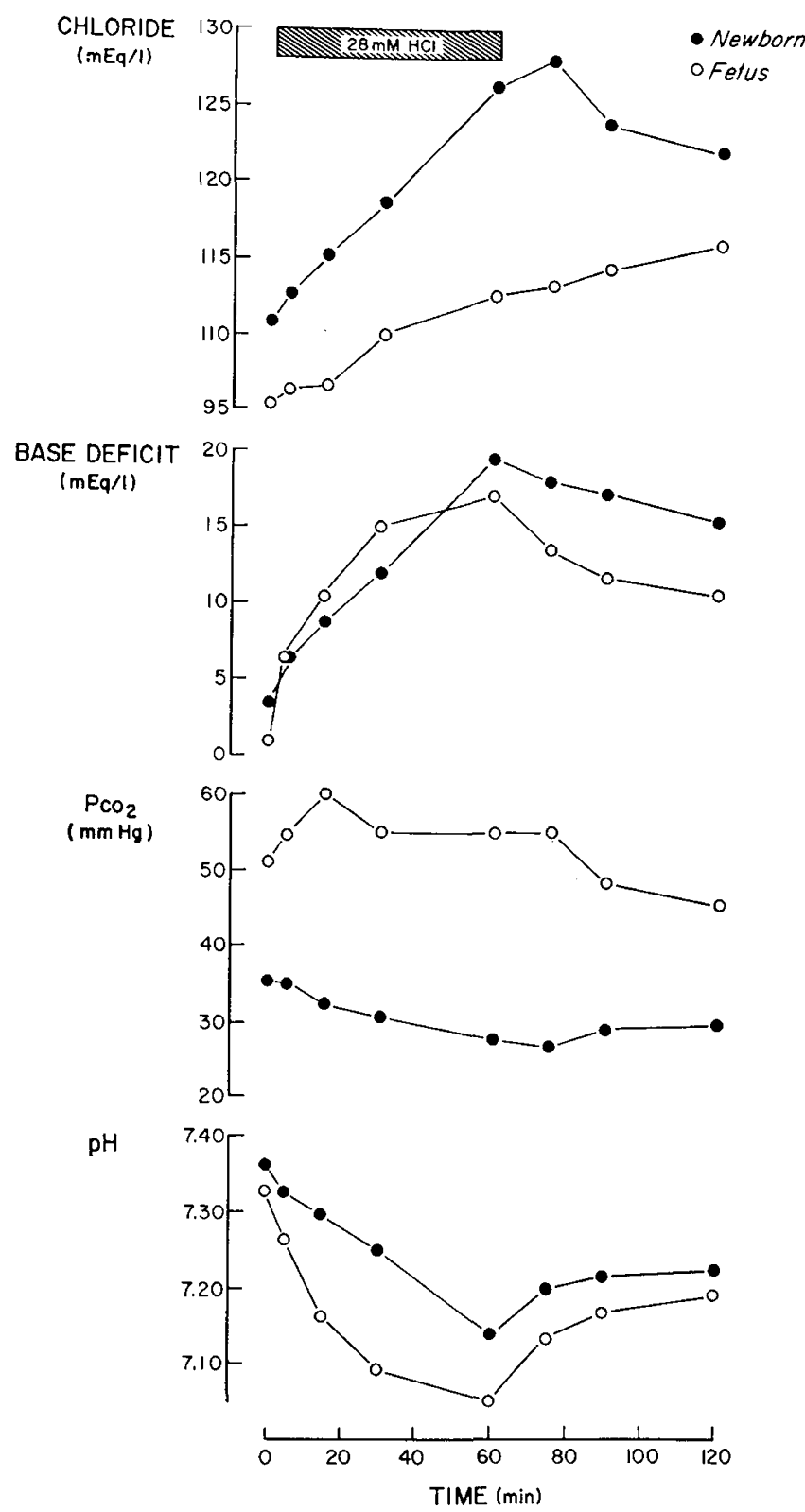

Fig. 2. Mean arterial $\mathrm{pH}, \mathrm{P}_{\mathrm{CO}_{2}}$, base deficit, and plasma chloride during and after hydrochloric acid infusion in fetal and newborn lambs. 
space $[8,17]$. In these experiments, the newborn lamb excreted only a minute portion of the acid load during and for the lst hr following infusion [10]. The initial fall in anion concentration in the fetus was comparable to that observed in the newborn. The continued increase in plasma chloride in the fetus after completion of infusion cannot readily be explained; the rise during infusion was less than that observed in the lactic acid experiments or in the newborn lambs. It is possible, inasmuch as chloride ion is confined to extracellular space, that water initially enters fetal extracellular fluid from intracellular fluid and placenta as a result of the hyperosmolar infusion. There could have also been an initial uneven distribution and delay in reaching equilibrium.

After the initial decrease in anion concentration, levels of chloride and lactate continued to decline more gradually, probably reflecting slow placental clearance. This slow clearance was anticipated in the case of chloride since Meschia and co-workers have shown that placental clearance of this anion is extremely low [28]. These experiments indicate that this is also true for lactate; the absence of a gradient for lactate in blood from the fetal femoral artery and umbilical vein supports this conclusion.

Recovery from lactic acidosis was somewhat faster than that from chloride acidosis, in both fetal and newborn lambs. Although part of the lactate must have been metabolized, judged by the rise in pyruvate levels (Table II), the absence of significant gradients of lactate and pyruvate between fetal arterial and umbilical vein blood indicates that the placenta is unlikely to be the primary site of lactate metabolism in the well oxygenated fetus. Although the placenta is capable of metabolizing both these substrates in vitro [32, 37], such metabolism by the placenta might occur only during some types of fetal hypoxia in which the placenta remains well oxygenated [21, 22]. The comparable rates of recovery from $\mathrm{HCl}$ and lactic acidosis in both fetus and newborn suggest that metabolism of lactate during the 1st hr of acidosis proceeds so slowly that it is cleared only slightly more rapidly than is chloride.

These experiments show that more than $1 \mathrm{hr}$ is re-
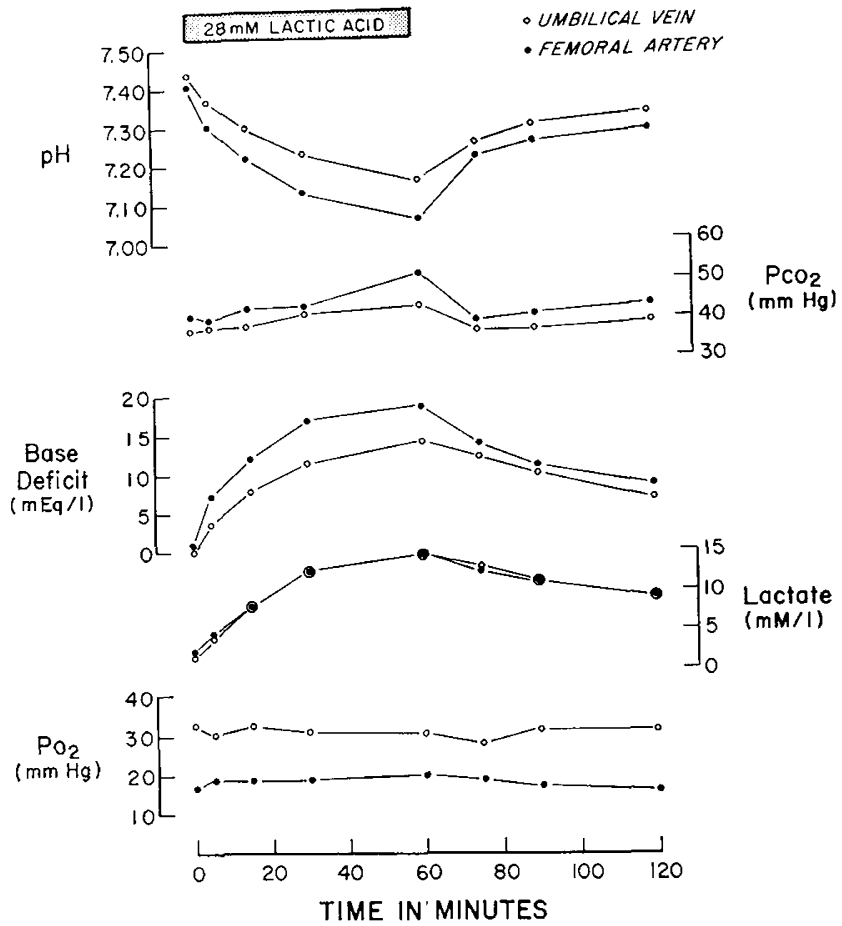

Fig. 3. Serial acid-base and lactate in femoral artery and umbilical vein in one fetus which received lactic acid infusion.

quired for blood lactate levels in the fetal lamb to be reduced by half. The corresponding time for base deficit is slightly less than $1 \mathrm{hr}$. With a single injection, Friedman et al. [16] determined that the half-life of ${ }^{14} \mathrm{C}$-lactate in blood of the fetal rhesus monkey was at least $15 \mathrm{~min}$. These investigators recognized that the actual biologic half-life, after distribution throughout the body compartments is complete, is probably much longer. It should be pointed out that the results from the present experiments with DL-lactic acid tend to indicate a slower rate, inasmuch as the $\mathrm{D}$ form can be utilized only after it has been converted to the endogenously produced L-lactic acid form [27, 29].

The newborn lamb hyperventilated markedly during and after the acid infusion and, as a consequence, was able to maintain a higher $\mathrm{pH}$ than the fetus for the same change in base deficit. In the fetus, the induced acidosis increased the arterial $\mathrm{P}_{\mathrm{CO}_{2}}$ probably as

Table III. Variables in ewe arterial blood before, at end of, and $1 \mathrm{hr}$ after infusion of acid to fetus in utero ${ }^{1}$

\begin{tabular}{lcccc}
\hline & $\mathrm{pH}$ & $\mathrm{PCO}_{2}, \mathrm{~mm} \mathrm{Hg}$ & $\mathrm{PCO}_{2}, \mathrm{~mm} \mathrm{Hg}$ & Base deficit, $\mathrm{mEq} / \mathrm{liter}$ \\
\hline Control & $7.49 \pm 0.013$ & $32.9 \pm 1.14$ & $95.4 \pm 3.46$ & $+2.0 \pm 1.44$ \\
End of infusion & $7.50 \pm 0.018$ & $33.6 \pm 1.37$ & $96.6 \pm 4.00$ & $+3.4 \pm 2.03$ \\
1 -hr recovery & $7.49 \pm 0.018$ & $30.6 \pm 2.10$ & $98.2 \pm 2.92$ & $+1.0 \pm 1.86$ \\
\hline
\end{tabular}

${ }^{1}$ Results of hydrochloric and lactic acid infusions have been pooled. Values are expressed as mean \pm standard error. 
a result of production of nonmetabolic carbon dioxide from bicarbonate buffer. The increased difference in $\mathrm{P}_{\mathrm{CO}_{2}}$ between umbilical arterial and venous blood and between umbilical and maternal arterial blood most likely reflects an increased placental transfer since neither umbilical nor uterine blood flow is altered by an acid infusion [20]. The ability of the fetus to compensate for metabolic acidosis would therefore seem to be limited by the level of maternal $\mathrm{P}_{\mathrm{CO}_{2}}$.

Several other investigators have studied the response of the exteriorized fetal lamb to an acid load. Vaughn and co-workers [35] found that the kidney of fetus and early neonate $j_{s}$ limited in its ability to acidify urine, and they concluded that the placenta probably excretes the largest portion of the acid load. By infusing a larger acid load at a slower rate, Smith and Schwartz [34] found a significant increase in hydrogen ion excretion in response to prolonged metabolic acidosis. Experiments described in this paper were focused on response of the feto-placental unit to an acid load rather than on renal excretion of acid. Our experimental conditions were different from those noted above [34, 35]; acid was infused with the fetus in utero rather than exteriorized, and there were also differences in total acid load and infusion rates. Therefore the results cannot readily be compared. Our conclusions agree in part with those of Vaughn and co-workers [35] that kidney excretes little of the acid load during the lst hr following infusion. However, during the same time, the placenta also excretes only a small portion of the acid load. Smith and Schwartz [34] observed a diuresis and increased renal excretion of hydrogen ion by the fetus when equilibrium had been established during and following infusion of a larger acid load over a longer period of time; the response was limited in comparison with that of adults.

Our experiments with the fetus intact in utero confirm that acute acidosis without accompanying hypoxia does not significantly alter fetal heart rate or blood pressure $[20,34,35]$. The increase in fetal oxygenation during acid infusion is also in agreement with the findings of Hellegers et al. [20] who studied the effect of fetal metabolic acidosis upon oxygen environment. The amount of acid transferred from fetus to mother was too small to cause measurable changes in maternal acid-base state; this also is in agreement with the findings of others $[20,34,35]$.

Acidosis following infusion of acid is not analogous to the acidosis of asphyxia. In asphyxia, acids produced in the cells move to extracellular fluid and blood, whereas, with infusion of acid, the movement of acid is from blood into extracellular fluid and cells. Furthermore, acidosis caused by asphyxia is mixed respiratory and metabolic acidosis. During recovery from asphyxia, there is initially a rapid rise in $\mathrm{pH}[1,23]$ owing to distribution of acid and excretion of carbon dioxide. Excretion of carbon dioxide is accompanied by a shift in bicarbonate from extracellular fluid to blood [13] and is reflected by a relatively rapid fall in base deficit. Once this movement of the "labile" component of base deficit has occurred, the residual fixed acids are excreted or metabolized relatively slowly. The recovery rate is then comparable to that observed in the present experiments following infusion of acid. Thus a rapid change in either $\mathrm{pH}$ or base deficit in the fetus does not indicate a rapid placental transfer of fixed acids, but rather recovery from an acute asphyxial episode, excretion of $\mathrm{CO}_{2}$, and a movement of the "labile" component of the base deficit.

Gresham and co-workers [19] have shown that, after fetal surgery, up to 4 days are required for fetal renal function to return to normal. It is probable, therefore, that, in the present experiments, fetal recovery from an acute acid load was achieved mainly by slow placental clearance of chloride or lactate. The likelihood remains that, if fetal renal function were optimal, handling of an acid load by the feto-placental unit might be better than the present experiments have indicated. It should be borne in mind, however, that renal blood flow is low in the asphyxiated fetus [4], and its recovery from the associated metabolic acidosis will be dependent upon the slow placental clearance.

The fetal lamb with the placenta as the major excretory organ is therefore not more capable of dealing with an acute acid load than is the newborn lamb. When acid concentration increases rapidly, recovery of the fetus from acidosis, even under ideal conditions, takes several hours to reach completion. This is probably also true of acids of maternal origin when the hydrogen ion gradient would be reversed. The slow transfer explains the wide range of concentration gradients in hydrogen, bicarbonate, and lactate ions between fetus and mother which are found if samples are taken before the circulations are stable and equilibrium has been established.

\section{Summary}

Metabolic acidosis was produced in fetal lambs in utero and in newborn lambs by infusion of hydrochloric or lactic acid. With a similar acid load, the fall in $\mathrm{pH}$ was greater in fetus than in newborn inasmuch as 
the latter was able to hyperventilate and partially to compensate for the metabolic acidosis. Ability of the fetus to lower $\mathrm{P}_{\mathrm{CO}_{2}}$ was limited by the maternal $\mathrm{P}_{\mathrm{CO}_{2}}$. Recovery from acute acid load was slow in both fetus and newborn, which reflects a slow placental transfer of hydrogen ion and anion. There seems to be little metabolism of lactate by either fetus or newborn during the lst hr following infusion. Ability of the feto-placental unit to handle an acute acid load is not superior to that of the newborn kidney.

\section{References and Notes}

1. Adamsons, K., Behrman, R., Dawes, G. S., James, L. S., and KoFOrD, C.: Resuscitation by positive pressure ventilation and tris-hydroxymethylaminomethane of rhesus monkeys asphyxiated at birth. J. Pediat., 65: 807 (1964).

2. Barker, S. B., and Summerson, W. H.: The colorimetric determination of lactic acid in biological material. J. Biol. Chem., 138: 535 (194I).

3. BEARD, R. W., AND MORRIS, E. D.: Foetal and maternal acidbase balance during normal labour. J. Obstet. Gynaecol. Brit. Commonw., 72: 496 (1965).

4. Behrman, R. E., Lees, M. H., Peterson, E. N., Delannoy, C. W., ANd Seeds, A. E.: Distribution of circulation in the normal and asphyxiated primate fetus. Amer. J. Obstet. Gynecol., 108: 956 (1970).

5. Blechner, J. N., Meschia, G., and Barron, D. H.: A study of the acid-base balance of fetal sheep and goats. Quart. J. Exp. Physiol. Cog. Med. Sci., 45: 60 (1960).

6. Blechner, J. N., Stenger, V. G., Etrzman, D. V., and ProsTowsky, H.: Effects of maternal metabolic acidosis on the human fetus and newborn. Amer. J. Obstet. Gynecol., 99: 46 (1967).

7. Bowe, E. T., Beard, R. W., Finster, M., Poppers, P. J., Adamsons, K., AND James, L. S.: Reliability of fetal blood sampling. Amer. J. Obstet. Gynecol., 107: 279 (1970).

8. Cневк, D. B., An appraisal of methods of tissue chloride analysis: the total carcass chloride, exchangeable chloride, potassium and water of the rat. J. Clin. Invest., 34: 1744 (1955).

9. Dancis, J., Worth, M., and Schneidau, P. B.: Effect of electrolyte disturbances in the pregnant rabbit on the fetus. Amer. J. Physiol., $51: 55$ (1957).

10. Daniel, S. S. Unpublished data.

11. Daniel, S. S., Adamsons, K., And James, L. S.: Lactate and pyruvate as an index of prenatal oxygen deprivation. Pediatrics, 37: 942 (1966).

12. Daniel, S. S., Sarcia, S., Bowe, E., Baratz, R., and James, L. $S$.: Elimination of hydrogen ion by the fetus and newborn (Abstr.). Annual Mtg. American Society for Pediatric Research, Atlantic City, 1969.

13. Dell, R. B., And Winters, R. W.: A model for the in vivo $\mathrm{CO}_{2}$ equilibration curve. Amer. J. Physiol., 219: 37 (1970).

14. Derom, R.: Anaerobic metabolism in the human fetus. Amer. J. Obstet. Gynecol., 89: 241 (1964).

15. Friedemann, T. E., and Haugen, G. E.: Pyruvic acid. II. The determination of keto acids in blood and urine. J. Biol. Chem., 147: 415 (1943).
16. Friedman, E. A., Gray, M. J., Grynfogel, M., Hutchinson, D. L., Kelly, W. T., and Plentr, A. A.: The distribution and metabolism of $\mathrm{C}^{1 *}$ labeled lactic acid and bicarbonate in pregnant primates. J. Clin. Invest., 39: 227 (1960).

17. Gamble, J. L., Robertson, J. S., Hannigan, C. A., Foster, C. A., AND FARR, L. E.: Chloride, bromide, sodium and sucrose spaces in man. J. Clin. Invest., 32: 483 (1953).

18. Goodlin, R. C., ANd Kaiser, I. H.: The effect of ammonium chloride induced maternal acidosis on the human fetus at term. I. PH, hemoglobin, blood gases. Amer. J. Med. Sci., 233: 662 (1957).

19. Gresham, E. L., Rankin, J. H. G., Makowskx, E. L., Meschia, G., AND BatTaglia, F. C.: An evaluation of fetal renal function in chronic preparation (Abstr.). Pediat. Res., 4: 445 $(1970)$.

20. Hellegers, A. E., Armstead, E. E., Thomas, C. E., Burnett, A. M., McGovern, T., AND Bruns, P. D.: Effect of fetal metabolic acidosis upon oxygen environment. Amer. $J$. Obstet. Gynecol., 105: 786 (1969).

21. Huckabee, W. E., Metcalfe, J., Prystowsky, H., and BarRON, D. H.: Movements of lactate and pyruvate in pregnant uterus. Amer. J. Physiol., 202: 193 (1962).

22. Huckabee, W. E., Metcalfe, J., Prystowsky, H., and BarRON, D. H.: Insufficiency of $\mathrm{O}_{2}$ supply to pregnant uterus. Amer. J. Physiol., 202: 198 (1962).

23. Hyman, A. I.: Sympathetic blockade in the asphyxiated fetus. (In preparation).

24. JAmes, L. S.: Acidosis of the newborn and its relation to birth asphyxia. Acta Paediat., 49 Suppl. 122: 17 (1960).

25. Joelsson, I., Barton, M. D., Daniel, S., James, L. S., ANd ADAMSONS, K.: A method for prolonged monitoring of physiologic functions during fetal life. Amer. J. Obstet. Gynecol., 107: 445 (1970).

26. KAISER, I. H., AND GoOdLIN, R. C.: Relations of $\mathrm{pH}$, gases and hemoglobin in blood and electrolytes in plasma of fetuses of diabetic mothers. Pediatrics, 22: 1097 (1958).

27. Lundholm, L.: The effect of D-lactic acid on the oxygen consumption and lactic acid content of the blood in rabbits. Acta Physiol. Scand., 45: 287 (1958).

28. Meschia, G., Battaglia, F. C., and Bruns, P. D.: Theoretical and experimental study of transplacental diffusion. J. Appl. Physiol., 22: 1171 (1967).

29. Myerhof, O., and LoHmanN, K.: Uber Atmung und Kohlehydratumsatz herische Gewebe. III. Uber der unterschied von d- und l-Milchsaure fur atmung und Kohlehydratsynthest un Organismus. Biochem. Z., 171: 421 (1921).

30. Oliver, T. K., JR., Demis, J. A., AND Bates, G. D.: Serial blood gas tensions and acid-base balance during the first hour of life in human infants. Acta Paediat., 50: 346 (1963).

31. Otey, E., Stenger, V., Ertzman, D., Andersen, T., Gessner, I., AND Prystowsky, H.: Movements of lactate and pyruvate in the pregnant uterus of the human. Amer. J. Ostet. Gynecol., 90: 747 (1964).

32. Roux. J. F., Hagerman, D. D., ANd Villee, C. A.: Effects of prolonged hypoxia on the metabolism of fetal rat tissues. Amer. J. Obstet. Gynecol., 84: 1309 (1962).

33. SiggaARd-Andersen, O.: Blood acid-base alignment nomogram. Scand. J. Clin. Lab. Invest., 15: 211 (1963).

34. Smith, F. G., AND Schwartz, A.: Response of the intact lamb fetus to acidosis. Amer. J. Obstet. Gynecol., 106: 52 (1970).

35. Vaughn, D., Kirschbaum, T. H., Bersentes, T., Dilts, P. V., 
ANd Assalx, N. S.: Fetal and neonatal response to acid loading in the sheep. J. Appl. Physiol., 24: 135 (1968).

36. VEDRA, B.: Acidosis and anaerobiosis in full term infants. Acta Paediat., 48: 60 (1959).

37. VILLEE, C. A.: The intermediary metabolism of human fetal tissues. Cold Spring Harbor Symp. Quant. Biol., 19: 143 (1954).

38. Harvard Apparatus, Millis, Mass.

39. Statham Instruments, Oxnard, Calif.

40. Radiometer, London Company, Cleveland, O.
41. Buchler Instruments, Fort Lee, N. J.

42. Supported by Public Health Service Research Grant no. G. M. 09069.

43. Dr. L. S. James is an Investigator, Health Research Council of the City of New York, Contract No. 1-148.

44. Requests for reprints should be addressed to: L. S. JAmes, M.D., Professor in Pediatrics, Columbia College of Physicians and Surgeons, 630 West I68th Street, New York, N. Y. 10032 (USA).

45. Accepted for publication January 6, 1972 .

\section{DATE DUE}

Hitem

